Vol-3, Issue-3, 2019 (IJEBAR)

E-ISN: 2614-1280 P-ISSN 2622-4771

http://www.jurnal.stie-aas/ijebar

\title{
THE USER SATISFACTION LEVEL OF E-LEARNING FOR BUSINESS AND MANAGEMENT SUBJECTS BASED ON TECHNOLOGY ACCEPTANCE MODEL
}

\author{
Indra Hastuti ${ }^{1)}$, Wijiyanto ${ }^{2)}$, Wiji Lestari ${ }^{3)}$, Sri Sumarlinda ${ }^{4)}$ \\ Faculty of Computer Science, Duta Bangsa University Surakarta \\ Email: hastuti.indra@yahoo.co.id
}

\begin{abstract}
E-learning is the implementation of information technology in learning. Elearning was used in courses in Introduction to Business and Management, Business Process Management and Ebusiness. This study aims to use the Technology Acceptance model (TAM) to measure the level of user satisfaction. TAM method is used to determine the relationship between content, accuracy, format, ease of use, timelines, organizational support, user attitudes towards the information system (user attitude towards information). system) and perceived attitude of top management on the level of satisfaction of using e-learning on learning business courses and management at the Faculty of Computer Science, Duta Bangsa University Surakarta. This research is a descriptive study using the modified End User Computing Satisfaction (EUCS) approach method. The results of the evaluation study show that the 5 variables (content), the level of accuracy of the system, format, easy of use, and timeliness significantly influence user satisfaction. While organizational support variables have a significant effect on user satifaction but variable usser attitude toward information system and perceived attitude of top management has an effect but not significant to the support organization.
\end{abstract}

Keywords: E-learning, user satisfaction, business and managements, technology acceptance model, end user computing satisfaction.

\section{Introduction}

The information technology increases rapidly and penetrates all areas of life. E-learning is one of the implementation of information technology in learning field. E-learning can be multimedia learning, educational games or web based learning. E-learning can improve the quality of learning because it is easily accessible, supports learning personalization, flexible time and so on (Cakir and Solak, 2014), (Abdullah and Toycan, 2018). Learning that uses student center learning model is very suitable for E-learning. In this model of learning students are subject to learning, lecturers and curriculum tools as supporting roles only (Rym et al., 2013).

The use of E-learning that provides many benefits also needs to be supported by the level of user satisfaction in this case students and lecturers (Rym et al., 2013), (Abdullah and Toycan, 2018). The satisfaction can be understood by simplify as a condition that illustrates what are person's needs, desires, and expectations are met after using certain products and or services (Baharin et al., 2015). The increasing use of software with various advantages as a computerbased information system is expected to increase the satisfaction of information users at companies or agencies that implement it (Vululleh, 2018). 
Vol-3, Issue-3, 2019 (IJEBAR)

E-ISN: 2614-1280 P-ISSN 2622-4771

http://www.jurnal.stie-aas/ijebar

The learning subjects related to management and business at the faculty of computer science of the Duta Bangsa University Surakarta has used E-learning. The course begins with an Introduction to Business and Management, Business Process Management and E-business (STMIK Duta Bangsa, 2016). The implementation of E-learning in the three courses went quite well, but user satisfaction has not been measured in the E-learning system used.

In this study the measurement of user satisfaction has been tested on the implementation of E-learning. The test was in the subjects of Introduction to Business and Management, Business process management and E-business using Technology accepted Model (TAM). The method of measuring the level of user satisfaction with TAM information technology has been widely used (Punnoose, 2012), (Kurniabudi et al., 2014), (Rym et al., 2013), (Abdullah and Toycan, 2018), (Adwan et al., 2013), (Tsai, 2015), (Baharin et al., 2015).

\section{Literature Review}

\subsection{Theory of Planned Behavior}

Theory of Planned Behavior (TPB) is a further development of the Theory of Reasoned Action (TRA). This construct is called perceived behavior control. This construct is added to TPB to control individual behavior which is limited by various shortcomings in resources to determine a behavior. There are several goals and benefits of this theory, among others, to predict and understand motivational influences on behavior that is not under individual control or will. To identify how and where to direct strategies for behavior change and also to explain to each important aspect some human behavior such as why someone takes courses in a particular field of study (Elkaseh et al., 2016), (Vululleh, 2018).

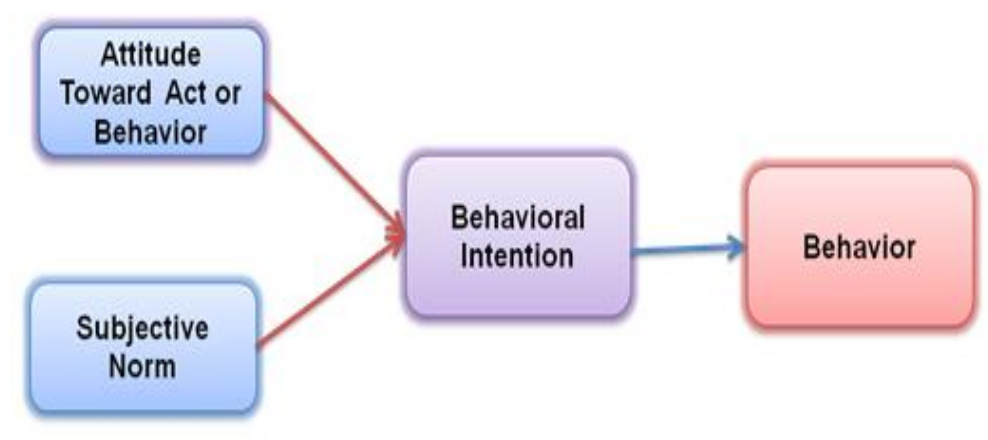

Figure 1. TRA Model

This theory provides a framework for studying attitudes toward behavior. Based on this theory, the most important determinant of a person's behavior is the intention / desire to behave. Individual intention to display a behavior is a combination of attitudes to display such behavior and subjective norms. Individual attitudes toward behavior include beliefs about behavior, evaluation of behavioral results, subjective norms, normative beliefs and motivation to obey.

\subsection{Technology Acceptance Model}

Technology Acceptance Model (TAM) is one of the models built to analyze and understand the factors that influence the acceptance of the use of information technology that was first introduced by Fred Davis in 1986. TAM is the result of the development of the Theory of Reasoned Action (TRA), which first developed. TAM aims to explain and estimate user 
Vol-3, Issue-3, 2019 (IJEBAR)

E-ISN: 2614-1280 P-ISSN 2622-4771

http://www.jurnal.stie-aas/ijebar

acceptance of an information system. TAM provides a theoretical basis to find out the factors that influence acceptance of a technology in an organization. TAM explains the causal relationship between beliefs (the benefits of an information system and the ease of use) and the behavior, goals / needs, and actual use of users of an information system (Punnoose, 2012), (Kurniabudi et al., 2014), (Rym et al., 2013), (Abdullah and Toycan, 2018), (Adwan et al., 2013), (Tsai, 2015), (Baharin et al., 2015).

The TAM model was adopted from the TRA model. TAM added two main constructs to the TRA model, namely perceived usefulness (perceived usefulness) and perceived ease of use. Both of these constructs have a direct influence on behavioral intentions (Kurniabudi et al., 2014), (Abdullah and Toycan, 2018), (Tsai, 2015), (Baharin et al., 2015). The TAM model can be seen in Figure 2.

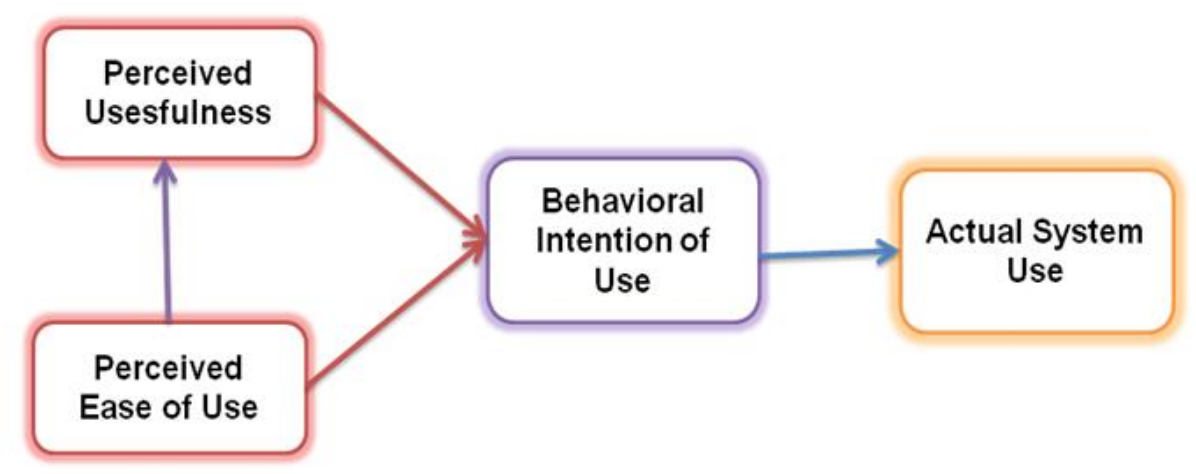

Figure2. TAM Model

One of the factors that can influence it is the user's perception of the usefulness and ease of use of information technology (IT) as a reasonable action in the context of technology users, so that someone's reason for seeing the benefits and ease of use of IT makes the person's behavior / behavior a benchmark in acceptance a technology (Cakir and Solak, 2014), (Vululleh, 2018).

\subsection{End-User Computing Satisfaction (EUCS)}

The measurement of satisfaction has a long history in the information system disciplines. Within the scope of end-user computing, a number of studies have been conducted to capture overall evaluations where end users have considered users of an information system (eg satisfaction) and also the factors that shape satisfaction (Kurniabudi et al., 2014), (Abdullah and Toycan, 2018), (Tsai, 2015), (Baharin et al., 2015).

End User Computing Satisfaction (EUCS) is a method to measure the level of satisfaction of users of an application system by comparing the expectations and reality of an information system. Definition of End User Computing Satisfaction of an information system is the overall evaluation of users of information systems based on their experience in using the system(Abdullah and Toycan, 2018), (Tsai, 2015), (Baharin et al., 2015). This EUCS evaluation model was developed by Doll and Torkzadeh. Evaluation using this model emphasizes end-user satisfaction with technological aspects, by assessing the content, accuracy, format, time and ease of use of the system. This model has been tested by other researchers to test its reliability and the results show that there is no significant difference even though this instrument is translated in different languages (Punnoose, 2012),(Elkaseh et al., 2016). 


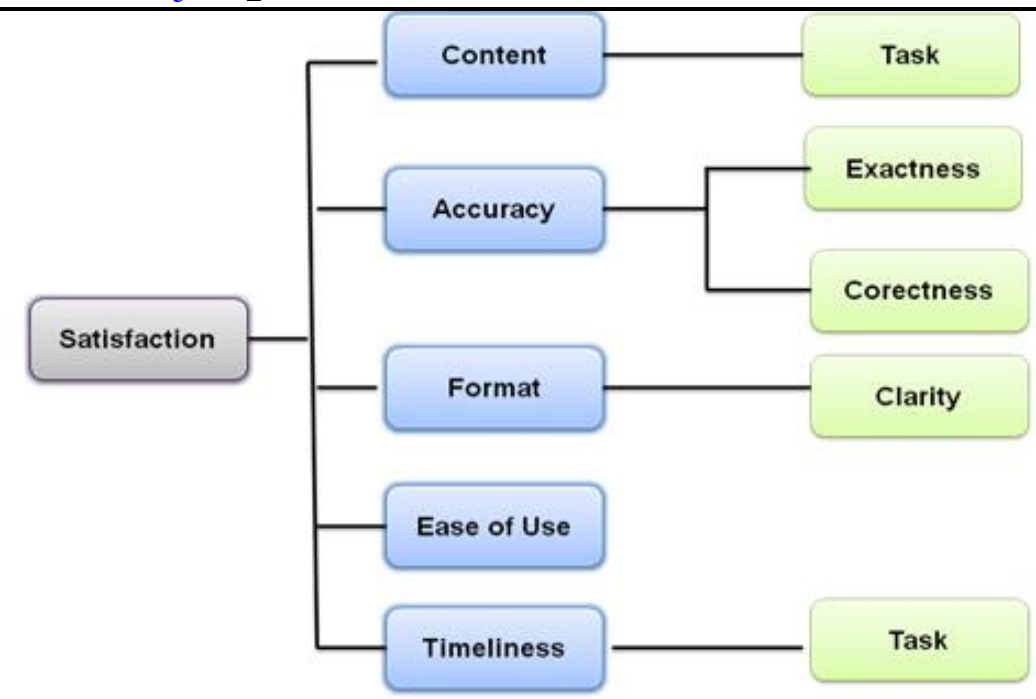

\subsection{E-learning}

Figure 3. Model EUCS

E-learning usually refers to learning methods that use electronic learning content. Web based learning is one example of E-learning. in general, usually called E-learning is web based learning.the increasing use of the internet, e-learning has now become a new method that is portable and flexible for students to acquire essential knowledge. At present e-learning is emerging as a new paradigm of modern education, especially for small and medium enterprises (Rym et al., 2013).

Many empirical studies support the idea that effective e-learning is beneficial to organizational success (Rym et al., 2013). The first asynchronous e-learning is a form of independent learning which is usually facilitated by media such as e-mail and discussion groups; support working relationships between students and teachers, even when participants cannot be online at the same time. As such, this is a key component of flexible e-learning (Rym et al., 2013), (Abdullah and Toycan, 2018). In contrast, synchronous e-learning allows interaction of real time and timely responses between instructors and students which are generally supported by media such as video conferencing and chat. This has the potential to support e-learners in the development of teach communities (Rym et al., 2013).

\section{Research Method}

Research involves several steps in a research framework unit. The flow of this research can be seen in. The flow of this research shows step by step that was passed during the research process.

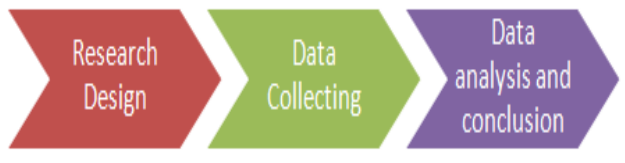

Figure 4.Research Diagram Flow

Judging from the type of problem faced by the type of research used in this study is descriptive research that is research on problems in the form of current facts of a population which includes activities to assess individual attitudes or opinions. Based on the type of data used, this study is included in empirical research that conducts research on facts obtained from 
Vol-3, Issue-3, 2019 (IJEBAR)

E-ISN: 2614-1280 P-ISSN 2622-4771

http://www.jurnal.stie-aas/ijebar

observation or experience. The object under study is emphasized on the actual events rather than people's perceptions of events. The type of data in this study is subject data, namely the type of research data in the form of opinions, attitudes or experiences of someone who is the subject of research (respondents). While the data sources used in this study are primary data. Primary data is research data obtained directly from original sources.

The population of this study were STMIK Surakarta Ambassadors students who attended the Introduction to Business and Management course, Business process Management and Ebusiness. In choosing a sample, this study uses a combined technique between convenient sampling and random sampling, researchers do not have other considerations for using convenient sampling except on ease. Someone was taken as a sample because by chance the person was in the place or incidentally the researcher knew the person. This type of sample is very good if it is used for exploratory research, which is then followed by further research in which the samples are taken randomly. However, a number of research cases that use this type of sample, show the results turned out to be less objective. For this reason, the researcher also used a random sampling technique which was conducted by questionnaire. For the purposes of data analysis, a minimum of 100 respondents is needed with consideration of the amount of data needed for the analysis process using SEM is at least 100.

The method of sampling in this study uses the Probability Sampling method that is with a simple random sample. The simple random sample method is sampling randomly from the population regardless of the strata in the population and each member of the population has the same opportunity to be sampled.

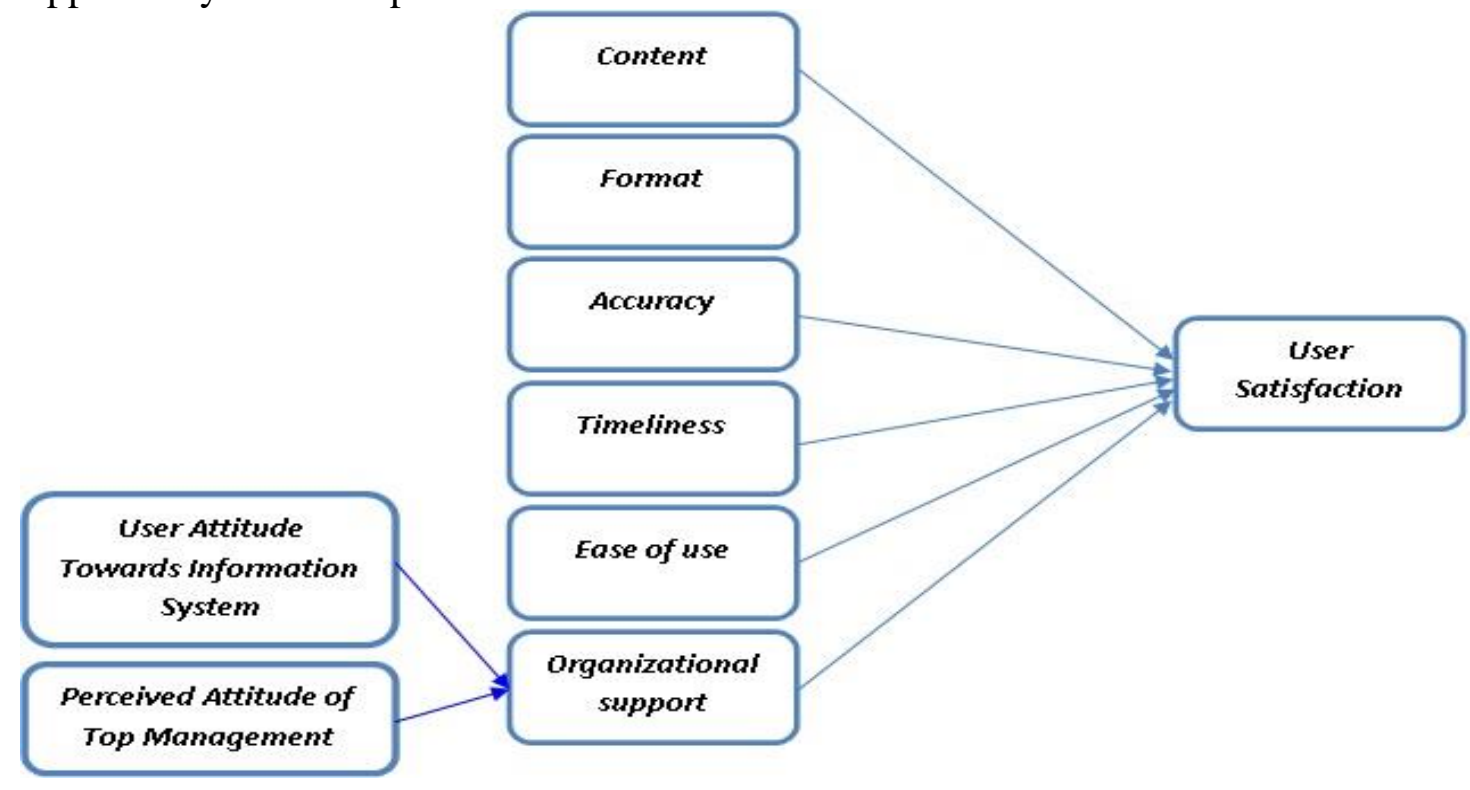

Figure 5. Research Framework

\section{Research Questionnaire}

In making research questionnaires, the variables and dimensions of the research variables will be used first. In this study the varaiabel / construct used in the questionnaire was based on variables contained in the EUCS (End User Computing Satisfaction) method in the study and used 
International Journal of Economics, Business and Accounting Research (IJEBAR)

Peer Reviewed - International Journal

Vol-3, Issue-3, 2019 (IJEBAR)

E-ISN: 2614-1280 P-ISSN 2622-4771

http://www.jurnal.stie-aas/ijebar

research as a modification. The variables and dimensions of the variables to be examined are as follows:

Table1. Research Questionnaire

Source : Baharin et al. (2015)

\begin{tabular}{|c|c|c|}
\hline Research variable & Variable Dimension & Item \\
\hline Content & $\begin{array}{l}\text { 1. E-learning provides material that } \\
\text { is adequate, useful and needed. } \\
\text { 2. E-learning provides useful } \\
\text { modules and practical examples. }\end{array}$ & 2 \\
\hline Accuracy & $\begin{array}{l}\text { 1. E-learning provides material that } \\
\text { is accurate and satisfying. } \\
\text { 2. E-learning provides information } \\
\text { in accordance with user access } \\
\text { rights. }\end{array}$ & 3 \\
\hline Format & $\begin{array}{l}\text { 1. E-learning has an attractive, } \\
\text { easyto understand and } \\
\text { harmonious appearance. } \\
\text { 2. E-learning has a useful and } \\
\text { satisfying format. }\end{array}$ & 5 \\
\hline Ease of use & $\begin{array}{l}\text { 1. E-learning has an easy-to-use } \\
\text { menu. } \\
\text { 2.E-learning can simplify and } \\
\text { improve the quality of learning. }\end{array}$ & 7 \\
\hline Timeliness & $\begin{array}{l}\text { 1. E-learning can be accessed by } \\
\text { the user quickly. } \\
\text { 2. E-learning provides up to date } \\
\text { material. }\end{array}$ & 9 \\
\hline
\end{tabular}


International Journal of Economics, Business and Accounting Research (IJEBAR)

Peer Reviewed - International Journal

Vol-3, Issue-3, 2019 (IJEBAR)

E-ISN: 2614-1280 P-ISSN 2622-4771

http://www.jurnal.stie-aas/ijebar

\begin{tabular}{|c|c|c|}
\hline Research variable & Variable Dimension & Item \\
\hline Organizational Support & $\begin{array}{l}\text { 1. I am satisfied with the speed of } \\
\text { the organization's response in } \\
\text { handling complaints } \\
\text { 2. The organization is effective in } \\
\text { dealing with problems that occur } \\
\text { in E-learning }\end{array}$ & 11 \\
\hline $\begin{array}{l}\text { User AttitudeTowards E- } \\
\text { learning System }\end{array}$ & $\begin{array}{l}\text { 1. E-learning is used by users } \\
\text { according to the rules. } \\
\text { 2. Users can provide input for } \\
\text { improvement and progress in } \\
\text { learning. }\end{array}$ & $\begin{array}{l}13 \\
14\end{array}$ \\
\hline $\begin{array}{l}\text { Perceived Attitudeof Top } \\
\text { Management }\end{array}$ & $\begin{array}{l}\text { 1. Faculty of computer Science } \\
\text { Duta Bangsa University } \\
\text { provided training using E- } \\
\text { learning. } \\
\text { 2. Faculty of Computer science } \\
\text { Duta Bangsa University } \\
\text { socializes E-learning usage. }\end{array}$ & 15 \\
\hline
\end{tabular}

\section{Result and Discussion}

Based on the results of the questionnaire distributed directly to the respondents collected as many as 62 respondents. Respondents were taken from students who had taken courses in Introduction to Business and Management, business process management and Ebusiness. After searching the data, 8 questionnaires were found to have invalid data so that for the remaining data processing 54 respondents.

The results of statistical calculations show the average value of each instrument varies between 2.83 to 3.96 . These results also show the usage behavior of the respondents. Where most respondents gave the opinion that E-learning provides material that is useful, easy to understand, easy to use and improve the quality of learning.

Table 1. Root Square of AVE

\begin{tabular}{|c|r|r|r|r|l|l|l|l|}
\hline & C & F & Acc & EoU & Time & OS & PAoTM & UATIS \\
\hline Content & 1 & & & & & & & \\
\hline Format & 0,257 & 1 & & & & & & \\
\hline Accuracy & 0,366 & 0,398 & 1 & & & & & \\
\hline Easy of Use & 0,344 & 0,525 & 0,149 & 1 & & & & \\
\hline
\end{tabular}


International Journal of Economics, Business and Accounting Research (IJEBAR)

Peer Reviewed - International Journal

Vol-3, IsSue-3, 2019 (IJEBAR)

E-ISN: 2614-1280 P-ISSN 2622-4771

http://www.jurnal.stie-aas/ijebar

\begin{tabular}{|c|l|l|l|l|l|l|r|r|}
\hline & C & F & Acc & EoU & Time & OS & PAoTM & UATIS \\
\hline Timeliness & 0,236 & 0,487 & 0,362 & 0,270 & 1 & & & \\
\hline $\begin{array}{c}\text { Org. } \\
\text { Support }\end{array}$ & 0,225 & 0,543 & 0,364 & 0,322 & 0,271 & 1 & & \\
\hline PaoTM & 0,226 & 0,417 & 0,379 & 0,343 & 0,656 & 0,336 & 1 & \\
\hline UATIS & 0,208 & 0,313 & 0,349 & 0,319 & 0,226 & 0,372 & 0,514 & 1 \\
\hline
\end{tabular}

After the model has been declared fit, there was no significant difference between the models tested with the sample matrix, then the next step was to the hypothesis test.

Table 2. The Hypothesis Test

\begin{tabular}{|c|c|c|c|c|c|c|}
\hline & & & Estimate & S.E. & C.R. & $\mathrm{P}$ \\
\hline OS & $<--$ & UATIS & .284 & .219 & 1.298 & .194 \\
\hline OS & $<---$ & PAoTM & .204 & .119 & 1.706 & .088 \\
\hline content 1 & $<---$ & Content & 1.000 & & & \\
\hline content 2 & $<---$ & Content & .843 & .222 & 3.751 & $* * *$ \\
\hline Format2 & $<---$ & Format & 1.000 & & & \\
\hline Format 1 & $<---$ & Format & 1.027 & .208 & 5.024 & $* * *$ \\
\hline Accuracy2 & $<---$ & Accuracy & 1.000 & & & \\
\hline Accuracy1 & $<---$ & Accuracy & 1.985 & .519 & 3.889 & $* * *$ \\
\hline Eou2 & $<---$ & EOU & 1.000 & & & \\
\hline Eou1 & $<---$ & EOU & .564 & .139 & 4.236 & $* * *$ \\
\hline Timeliness 2 & $<---$ & Timeliness & 1.000 & & & \\
\hline Timeliness 1 & $<---$ & Timeliness & .958 & .219 & 4.366 & $* * *$ \\
\hline OS1 & $<---$ & OS & 1.000 & & & \\
\hline OS2 & $<---$ & OS & 1.991 & .755 & 2.635 & .008 \\
\hline
\end{tabular}


International Journal of Economics, Business and Accounting Research (IJEBAR)

Peer Reviewed - International Journal

Vol-3, Issue-3, 2019 (IJEBAR)

E-ISN: 2614-1280 P-ISSN 2622-4771

http://www.jurnal.stie-aas/ijebar

\begin{tabular}{|c|c|c|c|c|c|c|}
\hline & & & Estimate & S.E. & C.R. & $\mathrm{P}$ \\
\hline UATIS2 & $<---$ & UATIS & 1.000 & & & \\
\hline UATIS1 & $<--$ & UATIS & 1.701 & .628 & 2.706 & .007 \\
\hline PaoTM2 & $<---$ & PAoTM & 1.000 & & & \\
\hline PAoTM1 & $<--$ & PAoTM & 1.239 & .255 & 4.867 & $* * *$ \\
\hline UserSatisfaction & $<--$ & Content & .148 & & & \\
\hline UserSatisfaction & $<--$ & Format & .123 & & & \\
\hline UserSatisfaction & $<--$ & Accuracy & .162 & & & \\
\hline UserSatisfaction & $<--$ & EOU & .112 & & & \\
\hline UserSatisfaction & $<--$ & Timeliness & .124 & & & \\
\hline UserSatisfaction & $<---$ & OS & .136 & & & \\
\hline
\end{tabular}

According to table 2, the result that all variables have a significant effect on the dependent variable. This is evidenced by the value of CR 961.96 and the value of P 50.05 is only the variable UATIS and PAoTM which have an effect but not significant because the CR value is CR 961.96 and the value of $\mathrm{P} \geq 0.05$. The results of the influence of content variables on user satisfaction can be seen in table 4.9. CR value on each content variable has a CR value of $\geq 1.96$ so that the content variable has a significant effect. Regarding the effect on user satisfaction can be seen that the estimate value in table $4.9 \geq 0$ then the content variable has a significant effect on user satisfaction.

This research can show that E-learning in the course of Introduction to Business and Management, Business Process Management and E-business that were developed by the Faculty of Computer science, Duta Bangsa University Surakarta, is seen in terms of content, system accuracy, display format, ease of use of the system, level of timeliness and organizational support has met the expectations of users, students and lecturers of Business and management. To find out the level of satisfaction of users of academic information systems, an evaluation was carried out by using a modification of the end user computing satisfaction model, so that five variables were obtained which significantly affected the satisfaction of users of academic information systems. Among others, content, format, accuracy, easy of use, and timeliness. Organizational support variables have a significant influence on user satisfaction, but the user attitude variable towards information system and perceived attitude of top management have an effect but not significant to organizational support.

\section{Conclusion}

Based on the discussion of the analysis results, this study can show that E-learning that is used for Introduction to Business Management, Business Process Management and E-business subjects, which is developed by faculty of Computer Science, Duta Bangsa University Surakarta 
Vol-3, Issue-3, 2019 (IJEBAR)

E-ISN: 2614-1280 P-ISSN 2622-4771

http://www.jurnal.stie-aas/ijebar

in terms of content, system accuracy, format display, ease of use of the system, the level of timeliness and support of the organization has met the expectations of users, stakeholders faculty of Computer science Duta Bangsa University Surakarta. To find out the level of user satisfaction E-learning for Business and Management introductory eyes,

Business Process management and E-business are evaluated using a modification of the end user computing satisfaction model, so that five variables can be significantly influenced by the satisfaction of users of academic information systems. Among others, content, format, accuracy, easy of use, and timeliness. Organizational support variables have a significant influence on user satisfaction, but the user attitude variable towards information system and perceived attitude of top management have an effect but not significant to organizational support.

\section{References}

Abdullah, M.S., Toycan, M. 2018. Analysis of the Factors for the Successful E-Learning Services Adoption from Education Providers' and Students' Perspectives: A case study of Private Universities in Northern Iraq. EURASIA Journal of Mathematics, Science and Technology Education 2018 14(3):1097-1109

Al- Adwan, A., Al- Adwan, A., Smedley, J. 2013. Exploring students acceptance of e-learning using Technology cceptanceModel in Jordanian universities. International Journal of Education and Development using Information and Communication Technology(IJEDICT), 2013, Vol. 9, Issue 2, pp. 4-18

Baharin, A.T., Latehb, H., Nathan, S.S., Mohd, H. 2015. Evaluating effectiveness of IDEWL using Technology AcceptanceModel. Procedia - Social and Behavioral Sciences 171 ( 2015 ) $897-904$.

Cakir, R., Solak, E. 2014. Exploring The Factors InfluencingE-Learning of Turkish EFLLearners Through TAM. TOJET: The Turkish Online Journal of Educational Technology - July 2014, volume 13 issue 3.

Elkaseh, A.M., Wong, K.W., and Fung, C.C. 2016. Perceived Ease of Use and Perceived Usefulness of SocialMedia for e-learning in Libyan Higher Education: AStructural Equation Modeling Analysis. International Journal of Information and Education Technology, Vol. 6, No. 3, March 2016.

Kurniabudi, Sharipuddin, Assegaff, S. 2014. A Literature Review: Acceptance Models for elearning Implementation in Higher Institution. International Conference on Advances in Education Technology (ICAET 2014).

Punnoose, A.C. 2012. Determinants of Intention to Use E-learning Based on the Technology Acceptance Model. Journal of Information Technology Education: Research, Volume 11, 2012.

Rym, B., Olfa, B., Ben M'BarekMélika, M. 2013. Determinants of E-Learning Acceptance: An Empirical Study in the Tunisian Context. American Journal of Industrial and Business Management, 2013, 3, 307-321.

Tsai, Yea-Ru. 2014. Applying the Technology Acceptance Model(TAM) to Explore the Effects of a CourseManagement System (CMS)-Assisted EFLWriting Instruction. calicovol 32.1 2015 153-171, 2014, equinox publishing.

Vululleh, Pee. 2018. Determinants of students' e-learning acceptance in developing countries: 
International Journal of Economics, Business and Accounting Research (IJEBAR)

Peer Reviewed - International Journal

Vol-3, Issue-3, 2019 (IJEBAR)

E-ISN: 2614-1280 P-ISSN 2622-4771

http://www.jurnal.stie-aas/ijebar

An approach based on Structural Equation Modeling (SEM). International Journal of Education and Development using Information and Communication Technology(IJEDICT), 2018, Vol. 14, ssue 1, pp. 141-151. 